\title{
The First Extensive Case-study on the Effects of Artificial Mycorrhization of Acer buergerianum Miq. in Hungary
}

\author{
K. Szabo ${ }^{1, *}$, V. Lovas ${ }^{2}$, Zs. Eros-Honti ${ }^{3}$ \\ ${ }^{1}$ Department of Garden and Open Space Design, Faculty of Landscape Architecture, Corvinus University of Budapest, Hungary \\ ${ }^{2}$ Department of Garden and Open Space Design, Faculty of Landscape Architecture, Hungary \\ ${ }^{3}$ Department of Botany, Faculty of Horticultural Science, Corvinus University of Budapest, Hungary
}

Copyright (C) 2015 by authors, all rights reserved. Authors agree that this article remains permanently open access under the terms of the Creative Commons Attribution License 4.0 International License

\begin{abstract}
Owing to the increasing environmental pollution and disturbances, afforestation of our cities has become an outlined objective by today. So as to elaborate liveable environments, the most important mission of breeders, gardeners and landscape architectures is to find such plant species and cultivars, which can tolerate urban conditions. Earlier, certain tree species later special cultivars of them were found to tolerate these environments, yet nowadays no such species or cultivars can be found that fulfil all requirements of urban afforestation. In this study, we examine the possibility of the application of artificial mycorrhizae with such purposes with a presumably appropriate species, Acer buergerianum (trident maple). Although Acer species are planted in parks rather than into tree lines, Acer buergerianum is one of the most popular trees in alleys of Eastern Asian cities. It is also included in the Urban Green Project 2021, while in Hungary it is only found as a solitaire species, mainly in botanical gardens. Owing to its good tolerance and high decorative value, it may play a potential role in future Hungarian urban afforestation. In our study, the effect of mycorrhizal products available in Hungary and different inoculation methods were tested on 120 trident maple specimens. Level of mycorrhization and phenological features indicating the growth intensity (thickness and height of the new shoots) were evaluated during the vegetative period.
\end{abstract}

Keywords Acer buergerianum, Trident Maple, Urban Afforestation, Endomycorrhiza, Inocula

\section{Introduction}

The genus Acer belongs to the Sapindaceae family. The majority of the 111 maple species live in the northern temperate climatic zone. Most species are deciduous, rarely evergreen trees or high shrubs. Because of the high number of taxa, the decorative value of the genus is various, yet most species are applied worldwide as ornamentals. Hungary has four native Acer species (Acer campestre L., A. platanoides L., A. pseudoplatanus L. and A. tataricum L.) living in different habitats, so they have somewhat different environmental needs [1, 2, 3, 4, 5].

The European afforestation of urban areas begun in the $18^{\text {th }}$ century with planting trees in urban outskirts. This had an important aim of providing recreation areas for the citizens in the close vicinity of the cities $[6,7]$. In Hungary, such ambition rose at the turn of $18^{\text {th }}$ and $19^{\text {th }}$ centuries, however, this urban afforestation remarkably accelerated from the 1860's [4]. Maples were planted in urban areas only after World War 2, when landscape designers and gardeners tended to plant native species into the cities [2]. From the 1960 's, the traffic began so intense that most frequent maple species were applied mainly in parks instead of tree lines. Some interesting and useful cultivars were bred at this period, such as 'Columnare', 'Deborah', 'Globosum', 'Olmsted', 'Summershade' of Acer platanoides or 'Negenia', 'Rotterdam' of Acer pseudoplatanus. These cultivars are considerably less sensitive to air and soil pollution characteristic of urban sites. Though in the first times some maple species were applied in alleys, and later their special cultivars of somewhat higher pollution tolerance survived in these areas, nowadays, with the increasing pollution burden of the cities, no native Acer species or cultivars serve entirely all the requirements.

As a solution, several non-native maples, like Acer buergerienum Miq. (trident maple) from Eastern China and Japan are planted lately in the European cities even up to an elevation of $1500 \mathrm{~m}$ amsl. This species is quite variable, and a number of varieties have been described already. It is a small to medium sized deciduous tree with rounded crown. Its shoots are bald. The leaves grow in opposite pairs, usually three-lobed, hard glossy green on the upper and pale green on the lower surface. On mature trees, the margin of the lobes are entire and its direction is forward pointing, but the leaf lobes of young plants are somewhat serrated and more spreading [4]. This species is the most frequent tree species in Japan. 
Several studies dealt with the role of fungi in urban environments $[8,9,10]$, and some of them focusing on the mycorrhizal colonisation of urban trees $[11,12,13,14,15$, 16]. All maples form endomycorrhizae association with fungi $[17,18]$. In case of trident maple growing in urban areas, the level of colonization was found to be significantly lower compared to those living in rural areas [14, 19]. Mycorrhizal Acer $\times$ freemanii and Acer buergerianum species were tested in a study on the effect of AM on the survival of the trees after their outplanting form the nursery. Field grown, balled and burlapped plants were treated with commercially available inocula, and one year after the transplantation, AM colonization levels and survival had increased in maples compared to the control plants [20]. Since the importance of AM symbioses is more pronounced in polluted and disturbed urban ecosystems than in natural ones [14], the effect of artificial mycorrhizal inoculation is intensely studied among such circumstances $[21,22,23,24$, 25]. Today, partial results of advantageous effects are available on the survival and growth rate of planted trees, including Acer buergerianum, in climatically different German towns, where the development of the inoculated plant specimens were better than without mycorrhizae [26].

In a large-scale study, nine different ornamental tree species were investigated all possessing potential roles in Hungarian urban afforestation: Acer buergerianum, Carpinus betulus, Fraxinus ornus, Ginkgo biloba, Magnolia kobus, Platanus sp., Sorbus borbasii, Tilia tomentosa, Ulmus pumila. Here we give the results on the trident maple. Our aim is to find a proper method and biological product for enhancing the growth and survival of trident maple trees among urban conditions. To reach this goal, we compared the phenological data and AM colonisation levels of trees treated with different inoculation techniques and differing mycorrhizal and/or bacterial inocula.

\section{Materials and Methods}

Experimental design: plants, products and experimental site

One-year-old seedlings of Acer buergerianum were obtained from nurseries. The effect of mycorrhizal or biological products obtainable in Hungary (licensed or not yet) were tested on 120 specimens (for the exact experiment arrangement see Table 1).

Biological products originated from two companies. Different inoculation methods were applied. A control set and another one of plants treated with fungicide were also set up. Product $\mathrm{C}$ did not contain any fungi but other microbes which help the plant's nutrient uptake. Products "A" and "D" (obtained from different companies) were applied for inoculation in the form of powder (A1, D1), suspension (A2, D3) or as a tablet (D2) (see Table 2).

Table 1. Examined species and mycorrhizal products during Hungarian pre-observation. (A, C, D treatments: different commercially available inocula for details see the text; *as suspension, ** as powder; *** as tablet).

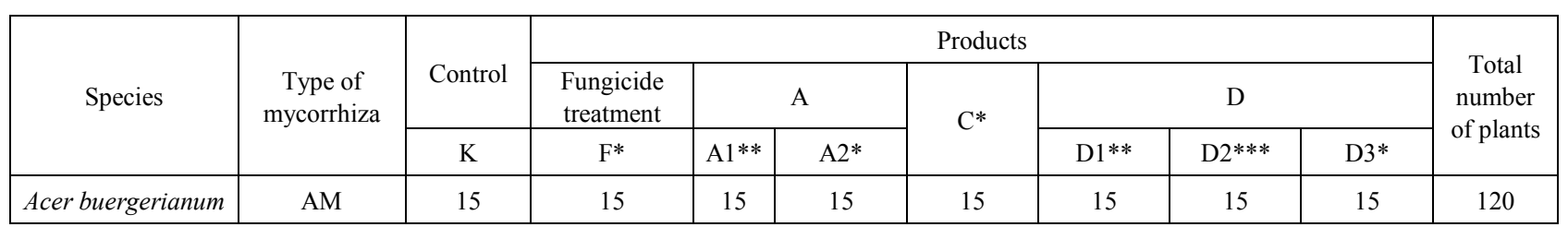

Table 2. Composition of examined biological products (according to the producers' descriptions).

\begin{tabular}{|c|c|c|c|c|}
\hline \multirow{2}{*}{ Composition } & \multirow{2}{*}{ Product A } & \multirow{2}{*}{ Product C } & \multicolumn{2}{|c|}{ Product D } \\
\hline & & & D1, D3 & D2 \\
\hline Substrate & Natural clay & suspension & \multicolumn{2}{|c|}{ high hygroscopy of the organic substrate } \\
\hline Mycorrhiza & $\begin{array}{l}100 \text { propagules/g (minimum } \\
\text { content) of six species of } \\
\text { mycorrhizal fungi }\end{array}$ & & $\begin{array}{l}\text { Glomus intraradices } \\
\text { - } 25 \text { spores } / \mathrm{g} ; \\
\text { Glomus moseae- } 25 \\
\text { spores } / \mathrm{g}\end{array}$ & $\begin{array}{c}\text { Glomus } \\
\text { intraradices }-150 \\
\text { spores /tablet; } \\
\text { Glomus moseae- } \\
150 \text { spores /tablet } \\
\end{array}$ \\
\hline $\mathrm{pH}$ & $6.0-8.0$ & & $6.5-7.0$ & 7.0 \\
\hline Organic matter & $\begin{array}{c}9,83 \% \text { of Humates, ground } \\
\text { mineral, extracts from sea } \\
\text { organisms. This product } \\
\text { contains naturally degradable } \\
\text { granules of a water-retaining } \\
\text { gel }\end{array}$ & $\begin{array}{l}\text { Azospirillum lipoferum, Azobacter vinelandii, } \\
\text { Bacillus megaterium, B. circulans, B. subtilis, } \\
\text { Pseudomonas flourescens, Micrococcus roseus, } \\
\text { other microorgans varietas and enzyme, } \\
\text { phytohormone, growing stimulant; average of } \\
\quad \text { total germ is min. } 5,2 \times 10^{9} \text { cells } / \mathrm{ml}\end{array}$ & \multicolumn{2}{|c|}{$\begin{array}{l}\text { presence of Planth Growth Promoting } \\
\text { Rhizobacteria, Trichoderma spp. }\left(10^{7}\right. \\
\text { spores/g) peptides of plant origin }\end{array}$} \\
\hline Applied Dosage & $7 \mathrm{~g} /$ plant & & $\begin{array}{l}\text { microgranules: } 2-3 \\
\text { g/plant }\end{array}$ & 1 tablet/plant \\
\hline
\end{tabular}


The experiment started in March 2014 within the area of the Botanical and Zoological Garden of Budapest. This area is close to air-polluted avenues, so the experimental specimens were grown among conditions being quite similar to those of tree lines of busy roadways. According to the data collected by the BP7 Honvéd data recorder station, the fly dust $\left(\mathrm{PM}_{10}\right)$ value of the study area in the winter of 2012-2013 exceeded the limit value with $14,7 \%$.

Root sampling and light microscopic analyses

Root samples were collected at two occasions. The first sampling was carried out right before planting and inoculation, whilst the second three months after inoculation. The total root system of 3 different healthy plants was collected at both occasions and from each treatment.

For examining mycorrhizal colonisation, the proper staining method was selected from several ones [27] by preliminary studies. After washing the soil out of the roots, they were cut into $1-\mathrm{cm}$-long pieces. For examining endomycorrhizae, we stained the roots with aniline blue. Prior to staining, roots were cleared with distilled water and discoloured by incubating them in $10 \%$ (wt/vol) $\mathrm{KOH}$ at $80^{\circ} \mathrm{C}$ in a dry block thermostat. Incubation time differed according to root thickness, yet it was app. 12-36 hours. Excess $\mathrm{KOH}$ solution was washed by rinsing the roots three times into tap water, then they were stored in slightly acidic solution (10 drops of cc. lactic acid). For staining, we used aniline blue dissolved in lactic acid (0,5 g/ $30 \mathrm{ml}$ lactic acid).
We stained the roots with heating the aniline blue solution to $80^{\circ} \mathrm{C}$ for 10 minutes in a dry block thermostat. Destaining was carried out by rinsing the roots in the lactic acid.

Stained samples laid on microscope slides (1) were examined in a grid-like manner based on previously marked detection points on the slide glasses. At each detection point, presence/absence of endomycorrhizal hyphae, arbuscules and vesicles were documented. The proportion of detection points with endomycorrhizal structures to the total number of detection points were calculated as percentage values.

We used Bio-TDB100 (Biosan) dry block thermostat for incubating the samples, Axio Imiger 2 (Zeiss) type microscope for analysis of samples, and AxioVision 4.8 version for photography.

\section{Evaluation of seedling development}

Initial plant material composed of seedlings was being leafy when planted. For monitoring the development, height and circumference of shoots were measured in spring and fall of 2014. Measured data were statistically compared to each other with the Past software [28]. Using ANOVA, pairwise post-hoc comparisons were accomplished with Tukey-test. Besides, date of bud burst and phenological stages were also documented in the spring of 2015. The following phenological stages were documented: dormant buds (0), swollen buds (1), burst buds (2) or elongated bud (3), and leafy (4). The observation time was between 22.03.2015 and 22.04.2015.

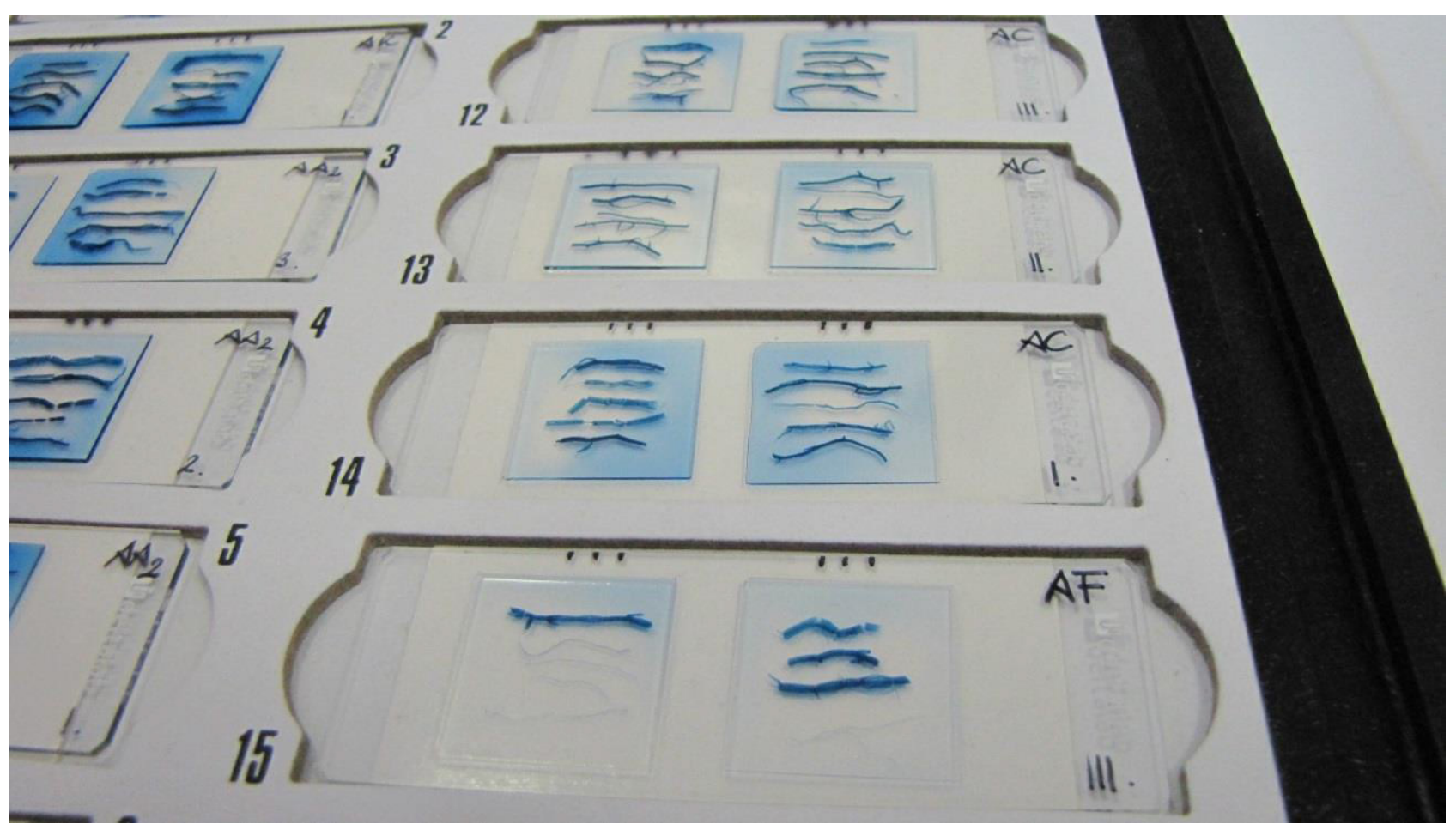

Figure 1. Root samples of Acer buergerianum prepared for evaluation. 
Table 3. AM colonization levels in different treatments.

\begin{tabular}{|c|c|c|c|c|}
\hline Exp. lines & Colonization & Arbuscle & Vesicle & Sum (\%) \\
\hline A1 & 19 & 5 & 7 & 21,11 \\
\hline A2 & 32 & 8 & 2 & 35,56 \\
\hline C & 14 & 4 & 13 & 15,56 \\
\hline D1 & 27 & 1 & 2 & 30 \\
\hline D2 & 6 & 1 & 3 & 6,67 \\
\hline D3 & 10 & 0 & 0 & 11,11 \\
\hline F & 3 & 0 & 4 & 3,33 \\
\hline K & 5 & & & 5,56 \\
\hline
\end{tabular}

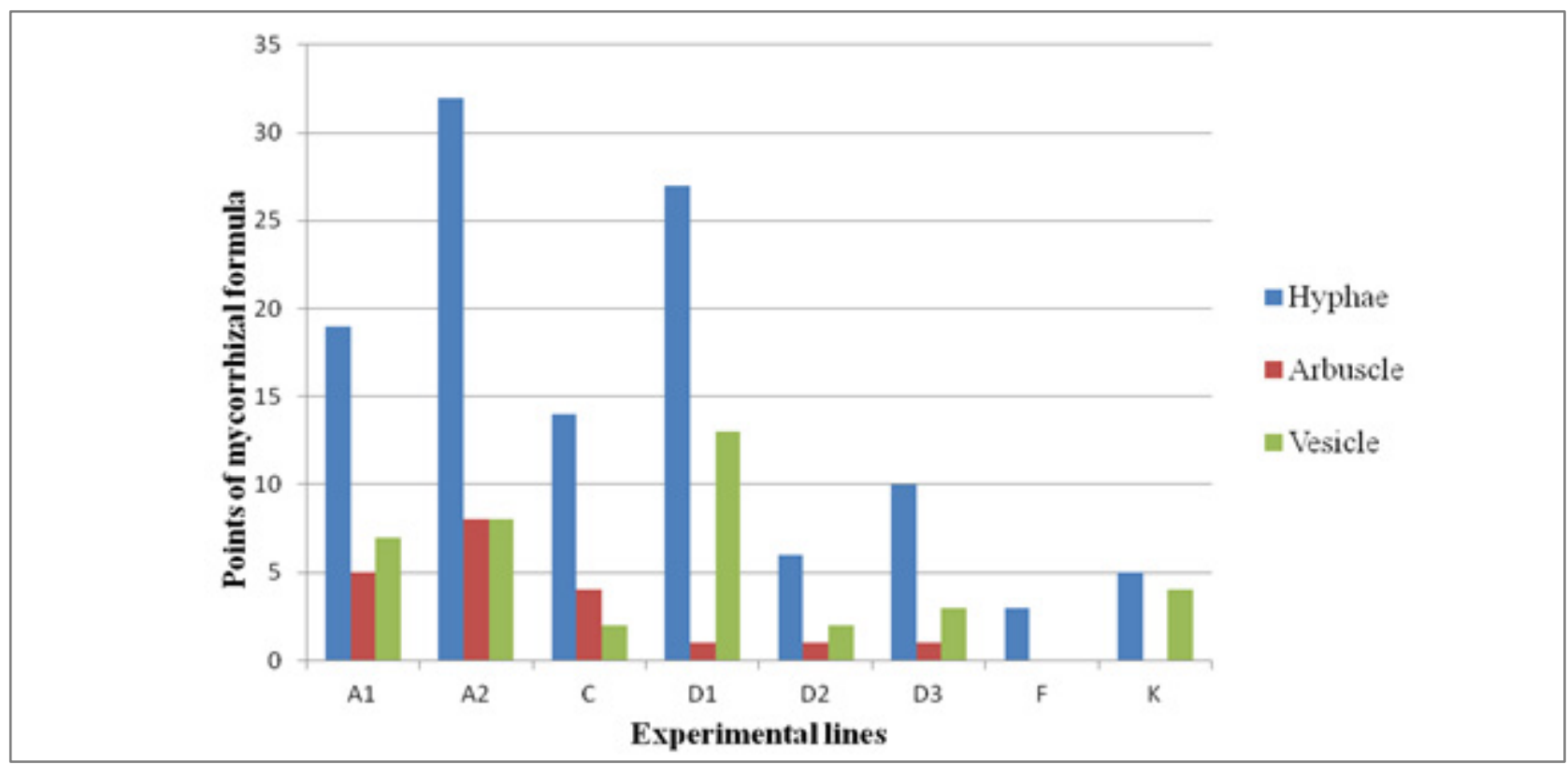

Figure 2. Presence of mycorrhizal structures in different treatments. (K control set; F fungicide treatment; C contains other microbes not fungi; A, D mycorrhizal products: A1, D1 powder, A2, D3 suspension, D3 tablet)

\section{Results and Discussion}

Mycorrhizal colonization of root sampling

Each treatment resulted in different levels of mycorrhizal colonisation. Hyphae, arbuscles and vesicles were detected in the roots of trident maple, but the degree of colonisation was different at the different treatments. The highest colonisation values (hyphae, arbuscles and vesicles, as well) were observed in treatment A2 (Table 3). The second highest values were found in treatment D1. Only hyphae were found in treatment F (fungicide), (Fig. (2)). In case of six treatments all three mycorrhizal structures were observed in the roots (Fig. (3). (4). (5)). However, mycorrhizal structures were also detected in the control plants, which indicated the presence of spontaneous colonisation from the soil of the study area. 


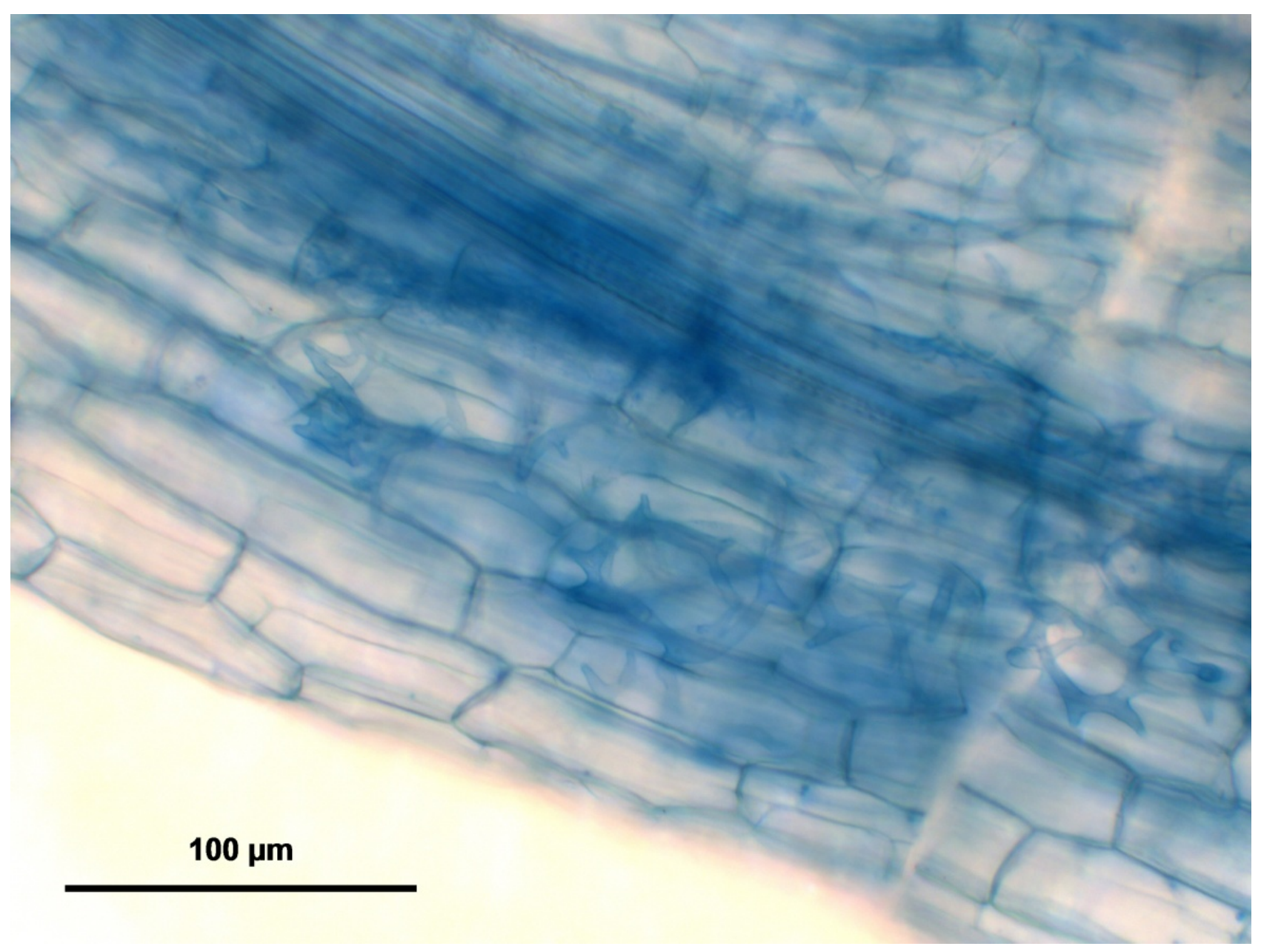

Figure 3. Dense hyphae structures in roots of Trident maple. 


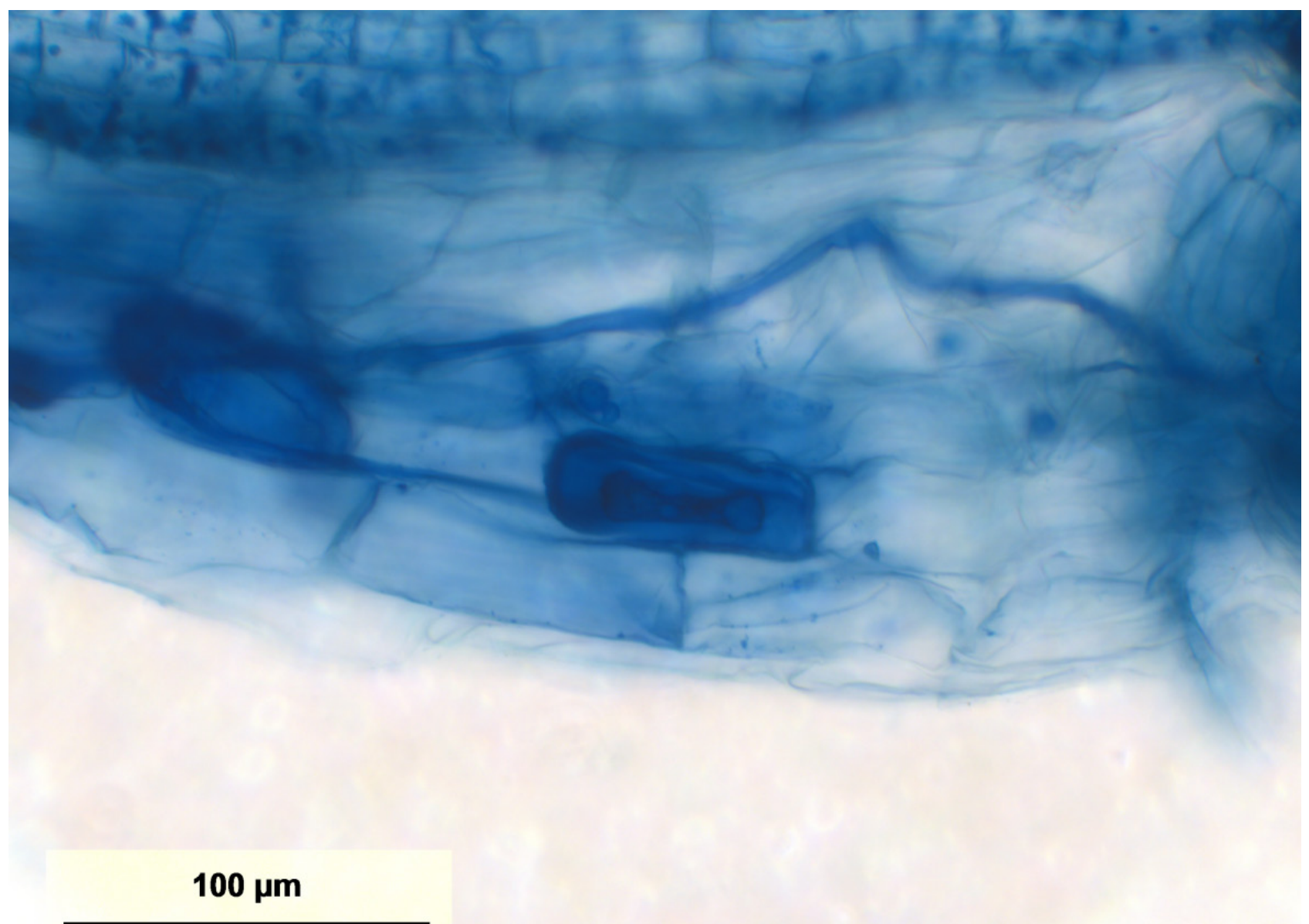

Figure 4. Well developed vesicles and hyphae in roots of Acer buergerianum plants of treatment D1. 


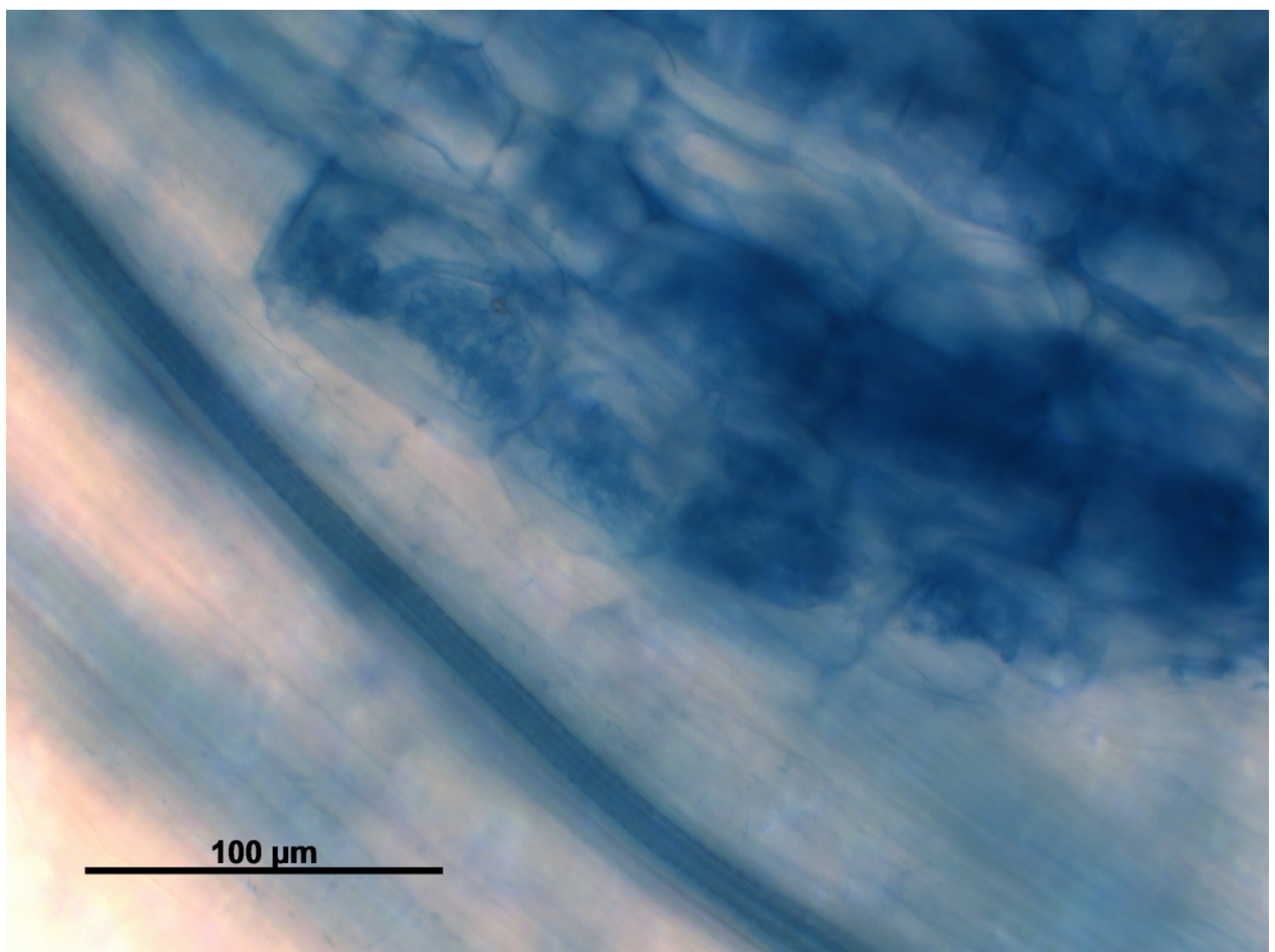

Figure 5. The branched arbuscles in plant of treatment $\mathrm{C}$.

Development of the trident maple seedlings

The initial values of shoot height and circumference were more uniform than that at the end of the observation period (Fig. (6) (A) and (B)). Although we investigated only the first year of development of the shoot heights were significantly different between A1, A2, K and F experimental lines. Prominent average value of shoot height was observed in treatment $\mathrm{K}(40.03 \mathrm{~cm})$, and then $\mathrm{A} 1, \mathrm{~A} 2$, but they were not significantly different. Lowest value was in treatment $\mathrm{F}(28.93 \mathrm{~cm})$. In occasion of initial shoot circumferences significantly different values were found $C$, D2, F plants of lines as compared with remaining lines. The highest average value was in treatment $\mathrm{K}(0.75 \mathrm{~cm})$ with in treatment A1 $(0.68 \mathrm{~cm})$ without significantly different and the value of average thickness was the significantly smallest in treatment D2 $(0.44 \mathrm{~cm})$. At the second sampling occasion, only the measured height and circumference values of the plants of treatment D2 were significantly different from those measured in other treatments (in Fig. (6) (C) and (D)). The lowest was D2 in both measurements, data of shoot height was $60.67 \mathrm{~cm}$ and shoot interference was $1,07 \mathrm{~cm}$. The highest value, in occasion shoot height was treatment A1 $(89.23 \mathrm{~cm})$ and in occasion shoot interference was treatment F $(1.9 \mathrm{~cm})$ see in Fig. (6) (E) and (F). Plants of treatments C $(52.46 \mathrm{~cm}) \mathrm{A} 1, \mathrm{D} 1$ and $\mathrm{F}$ showed outstanding increases in shoot height, yet this value was not significantly different among them. Increase in shoot circumference was significantly the highest in treatment $F(1.41 \mathrm{~cm})$. The significantly lowest increase values were observed in treatment D2 $(25.28 \mathrm{~cm}$ in height and $0.61 \mathrm{~cm}$ increase in thickness). This difference could issue from different genetically materials and divergent root developing. In the comparison of different mycorrhizal product the standard deviation of shoot height in vegetative period was similar except for experimental D2 as tablet, where the values not only in height but circumference of shoot were lower than any other experimental lines. The treatment with bacterium (C) was advantageous for the height and circumference development of the shoots. 

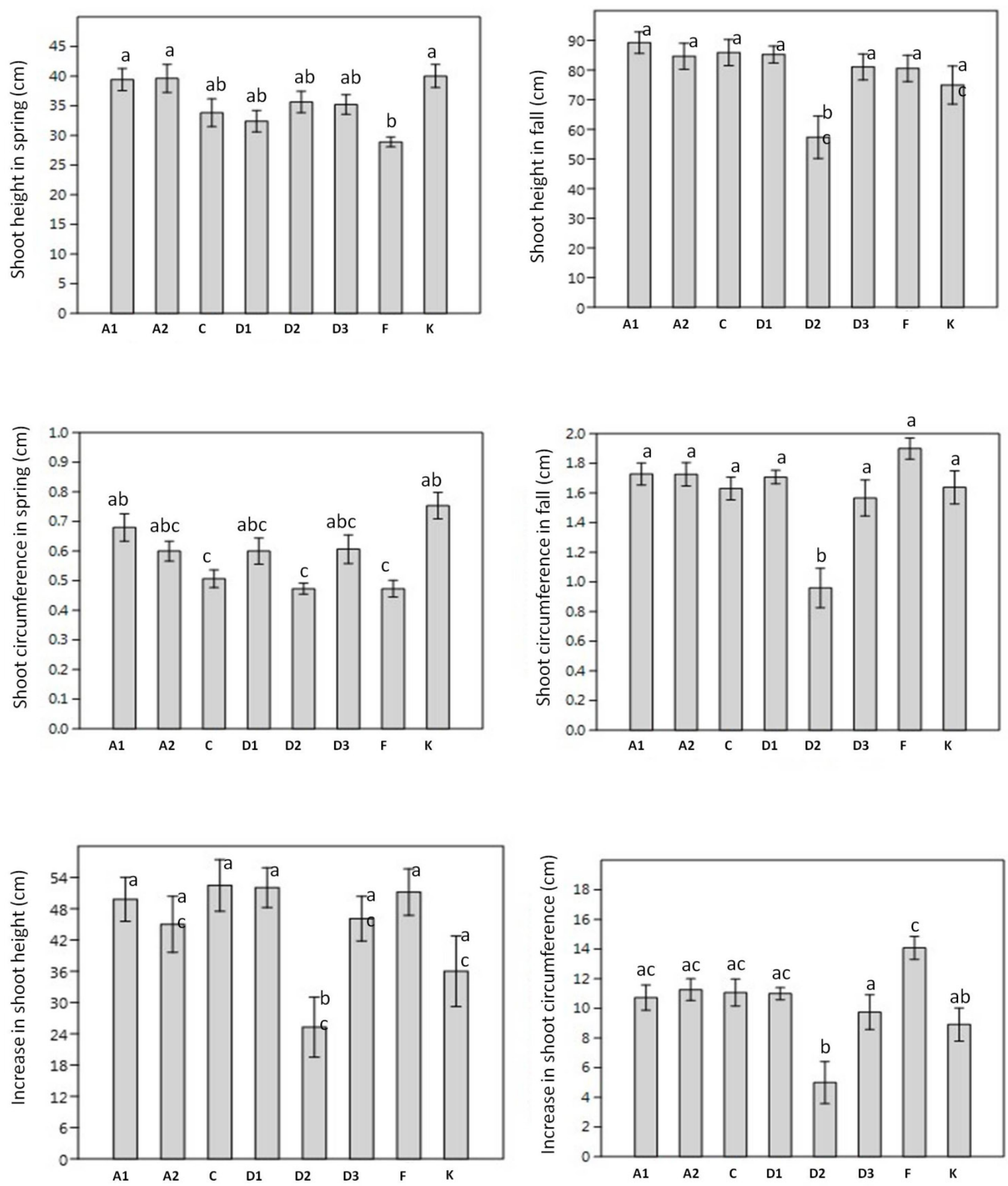

Figure 6. Measured values and statistical comparisons of phenological data (A) initial shoot height, (B) initial shoot circumference, (C) shoot height in fall, (D) shoot circumference in fall, (E) increase shoot height and (F) increase shoot circumference in fall. Means not sharing the same letters are significantly different $(\mathrm{p}=0,01)$.). 


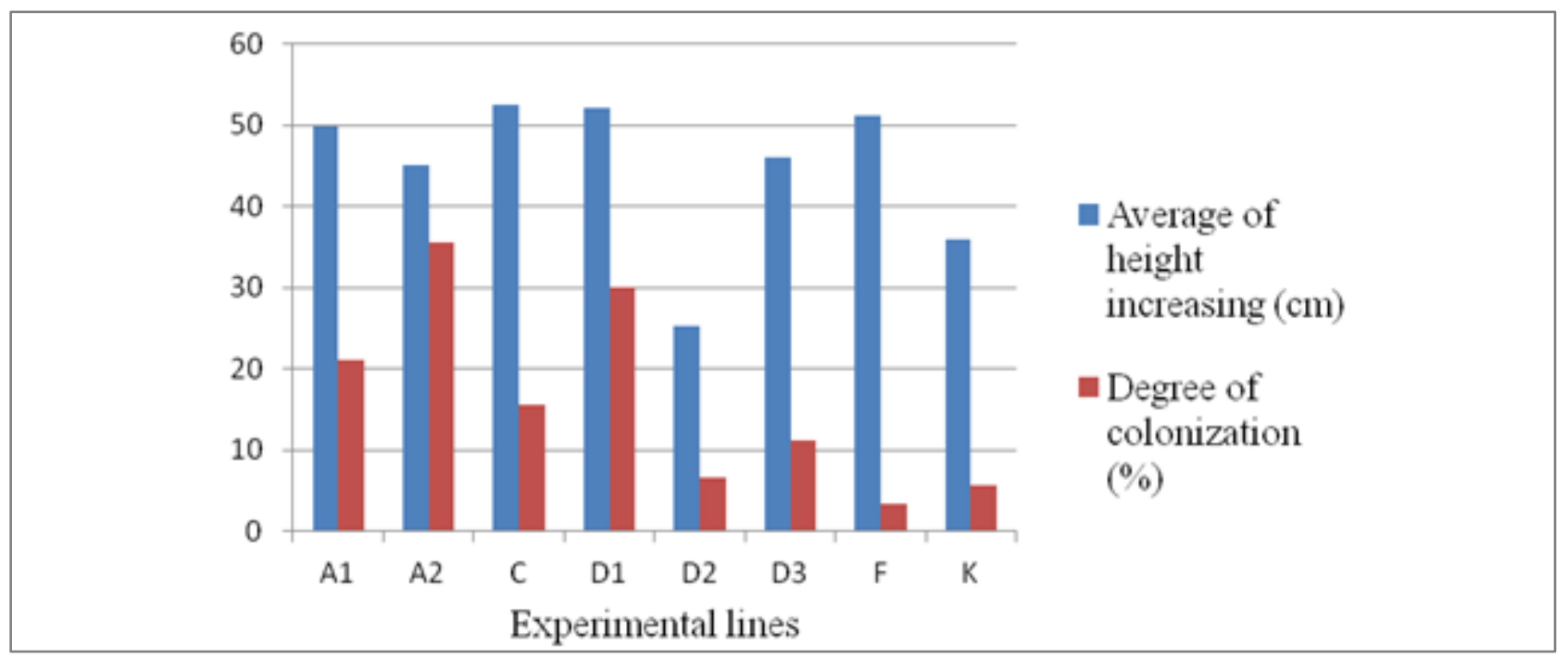

Figure 7. Relation between colonization (\%) and mean height increas (cm).

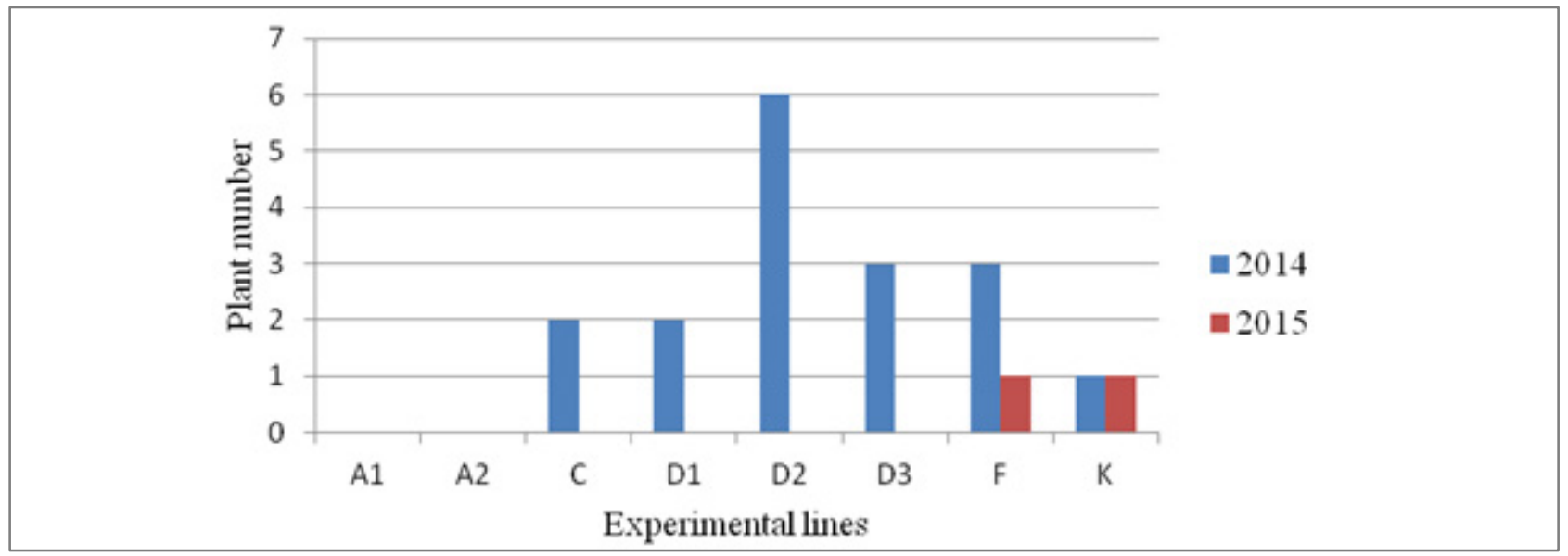

Figure 8. Trend of mortality in experimental plants till 2015 spring.

Relations between mycorrhizal colonization and plant development

Increased colonization level did not necessarily coincided with the increase of shoot height and circumference in Fig. (7). The best colonization rate was observed in treatment A2 which also resulted the best increase in shoot height and second best values in the increase of shoot circumference. However, the lowest colonization level was found in treatment F, which was not in parallel either with the shoot height or the thickness of the shoot. The reason for this might is that the fungicide killed such pathogens that may have hindered the growth of the seedlings.

\section{Seedling mortality}

In the first year there were several plants died probably owing to the rooting problems. In the second year, such events were only observed in experimental lines treated with fungicide $(\mathrm{F})$ and in the control lines (K) (Fig. (8)). The highest mortality rate was found in treatment D2 in the first year, yet valuable is the fact that among plants treated with any biological products no dying out was observed in the second year.

\section{Bud development}

The budding completely finished within about one month. The difference of budding was conspicuous, since in treatments D1, D2, D3 and C it started earlier compared to the other treatments (see Table 4). Nevertheless, later these lines were caugth up by the other plants. Moreover plants of treatments D1, D2, D3 and C reached the total leafy state only by the fourth experimental week, while A2, C, F speciments were leafy by the third week. 
Table 4. Rythm of budding of plants in different experimental line $\sin 2015$ spring where 0 - bud, 1 - swollen bud, 2 - burst, 3 - elongated bud and 4 - leafy were.

\begin{tabular}{|c|c|c|c|c|c|c|c|c|c|c|c|c|c|c|c|c|c|c|c|c|c|}
\hline \multicolumn{10}{|c|}{ Phenological states (\%) } \\
\hline \multirow{2}{*}{$\begin{array}{c}\text { Exp. } \\
\text { lines }\end{array}$} & $\mathbf{9}$ & $\mathbf{1}$ & $\mathbf{2}$ & $\mathbf{3}$ & $\mathbf{4}$ & $\mathbf{0}$ & $\mathbf{1}$ & $\mathbf{2}$ & $\mathbf{3}$ & $\mathbf{4}$ & $\mathbf{0}$ & $\mathbf{1}$ & $\mathbf{2}$ & $\mathbf{3}$ & $\mathbf{4}$ & $\mathbf{0}$ & $\mathbf{1}$ & $\mathbf{2}$ & $\mathbf{3}$ & $\mathbf{4}$ \\
\hline $\mathbf{A 1}$ & - & 66,7 & - & 33,3 & - & - & 13,3 & - & 33,3 & 53,3 & - & - & - & 13,3 & 86,7 & - & - & - & - & 100 \\
\hline A2 & - & 60 & - & 40,0 & - & - & 6,7 & - & 46,7 & 46,7 & - & - & - & & 100 & - & - & - & - & 100 \\
\hline C & - & - & - & 100 & - & - & - & - & 69,2 & 30,8 & - & - & - & & 100 & - & - & - & - & 100 \\
\hline D1 & - & - & - & 100 & - & - & - & - & 30,8 & 69,2 & - & - & - & 7,7 & 92,3 & - & - & - & - & 100 \\
\hline D2 & - & - & 11,1 & 88,9 & - & - & - & - & 33,3 & 66,7 & - & - & - & 11,1 & 88,9 & - & - & - & - & 100 \\
\hline D3 & - & 33,3 & - & 66,7 & - & - & - & - & 33,3 & 66,7 & - & - & - & 25 & 75 & - & - & - & - & 100 \\
\hline F & 50 & 50 & - & & - & 8,3 & - & - & 33,3 & 58,3 & - & - & - & & 100 & - & - & - & - & 100 \\
\hline K & 42,9 & - & - & 57,1 & - & 7,1 & - & - & - & 92,9 & 7,1 & - & - & & 92,9 & - & - & - & - & 100 \\
\hline
\end{tabular}

\section{Conclusions}

Our here presented experimental results on the trident maple support the fact that the artificial mycorrhization techniques used for ornamental plants might increase the level of mycorrhizal colonisation of the plant specimens. However, similarly to other authors [29, 30, 31, 32] the beneficial effects greatly depended on the specific product and the method of inoculation (suspension, tablet etc.). The phenological changes (shoot growth, survival, budding) of inoculated plants mostly, but not always correlated with the changes in the level of mycorrhization. We also found relation between colonization level and plant development. According to our results, tablet form of mycorrhizal inoculum was the less advantageous for the trident maple plants concerning the colonization level, shoot development and mortality rate, as well. The product applied in treatment A2 in the form of suspension resulted the best colonization levels and it was also in the forefront in case of shoot development and budding. Mortality rate of plants in this treatment was zero, therefore, the artificial product $\mathrm{A}$ in suspension form (A2) can be recommended for treatment based on our results.

Our results stress the necessity of prelimiray studies before any mycorrhizal inoculation method is applied in large scale in urban afforestation.

\section{Conflict of Interest}

The authors confirm that this article content has no conflict of interest.

\section{Acknowledgements}

This work was supported by the project TÁMOP-4.2.1/B-09/1/KMR-2010-0005 of the Faculty of Landscape Architecture and Faculty of Horticultural Science. We are grateful to Gábor $M$. Kovács for his valuable inspiration and advices for the Hungarian project.

\section{REFERENCES}

[1] Schmidt, G. (szerk) Növények a kertépítészetben, Mezőgazda Kiadó, 2003; pp. 243-251.

[2] Schmidt, G.; Honfi, P. Budapesti fák élete és halála. Budapest folyóirat 2006, 29 (7), 2-6.

[3] Tuba, Z.; Szerdahelyi, T.; Englomer, A.; Nagy, J. Botanika III. Bevezetés a növénytanba, algológiába, gombatanba és a funkcionális növénybiológiába. Nemzeti Tankönyvkiadó. Budapest, 2007.

[4] Tóth, I. Lomblevelü díszfák, díszcserjék kézikönyve. Tarkavirág Kereskedelmi és Szolgáltató Kft., Dunaharaszti, 2012.

[5] Bölöni, J.; Molnár, Zs.; Kun, A. Magyarország élőhelyei. Vegetációtípusok leírása és határozója. ÁNÉR 2011. MTA Ökologiai és Botanikai Kutatóintézete, Vácrátót, 2011.

[6] Csérer, Gy. A város és a falu fásítása, M. Kir. Belügyminisztérium, Budapest, 1928.

[7] Radó, D. Fák a betonrengetegben, Mezőgazdasági Kiadó, Budapest, 1981.

[8] Harley, J.L.; Harley, E.L. A check-list of mycorrhiza in the British flora. New Phytol., 1987, 105, 1-102.

[9] Wang, B.; Qiu, Y-L. Phylogenetic distribution and evolution of mycorrhizas in land plants. - Mycorrhiza, 2006, 16, 299363.

[10] Szabó, K.; Böll, S.; Erős-Honti, Zs. Applying artificial mycorrhizae in planting urban trees. Applied Ecology and Environmental Research, 2014, 12(4): 835-853.

[11] Gáper, J. The classification of ectotrophic mycorrhizas on Betula verrucosa in the urban area. Agriculture, Ecosystems \& Environment 1989, 28(1-4), 145-149.

[12] Baxter, J.W.; Pickett, S.T.A.; Carreiro, M.M.; Dighton, J. Ectomycorrhizal diversity and community structure in oak 
forest stands exposed to contrasting anthropogenic impacts, Can.J.Bot., 1999, 77, 771-782.

[13] Timonen, S.; Kauppinen, P. Mycorrhizal colonisation patterns of Tilia trees in street, nursery and forest habitats in southern Finland. Urban Forestry \& Urban Greening, 2008, 7(4), 265-276.

[14] Bainard, L.D.; Klironomos, J.N.; Gordon, A.M. The mycorrhizal status and colonization of 26 tree species growing in urban and rural environments. Mycorrhiza., 2011, 21, 91-96. http://link.springer.com/article/10.1007/s00572-010-0314-6

[15] Karpati, A.S.; Handel, S.N.; Dighton, J.; Horton, T.R. Quercus rubra-associated ectomycorrhizal fungal communities of disturbed urban sites and mature forests. Mycorrhiza, 2011, 21(6), 537-547.

[16] Karliński, L.; Jagodziński, A.M.; Leski, T.; Butkiewicz, P.; Brosz, M.; Rudawska, M. Fine root parameters and mycorrhizal colonization of horse chestnut trees (Aesculus hippocastanum L.) in urban and rural environments. Landscape and Urban Planning, 2014, 127, 154-163.

[17] Kuhns, L.J. Potential benefits of mycorrhizae int he urban environment. Proceeding of the third conference of the Metropolitan Tree Inprovement Alliance (METRIA). Held at Rudgers The State University of New Jersey June 18-20, 1980.

[18] Moore, D.; Robson, G.D.; Trinci, A.P.J. 21st Century Guidebook to Fungi. Cambridge University ISBN: 9780521186957. 2011.

[19] Tyburska, J.; Frymark-Szymkowiak, A.; Kulczyk-Skrzeszewska, M.; Kieliszewska-Rokicka, B. Mycorrhizal status of forest trees grown in urban and rural environments in Poland. Ecological Questions, 2013, 18(1), $49-57$.

[20] Wiseman, P.E.; Wells, C.E. Arbuscular Mycorrhizal Inoculation Affects Root, Development of Acer and Magnolia Species. J. Environ. Hort., 2009, 27(2), 70-79.

[21] Gianinazzi, H.; Schuepp, H.; Barea, J. M.; Haselwandter, K. (eds.), Mycorrhiza Technology in Agriculture: from Genes to Bioproducts. Birkhäuser, Switzerland, 2002.
[22] Young, C.C. Development and application of biofertilizers in Taiwan, Extension Bulletin - Food \& Fertilizer Technology Center, 2005, 565, 1-7.

[23] Schneider, C.; Feldmann, F. Qualität von Mykorrhizapräparaten. bi Galabau, 2007, 1-2, 3-6.

[24] Feldmann, F. Mycorrhiza for plant vitality: mycorrhizal fungi as factors of integrated horticultural plant production. - In: Feldmann, F.; Kapulnik Y.; Baar, J. (eds): Mycorrhiza Works. DPG Publisher Braunschweig, Germany, 2008, pp. 7-17.

[25] Lanthier, M. Mycorrhizal inoculation of nursery trees: benefits for arborists. North Okanagan Organics Association Workshops on Soil Biology 2009.

[26] Böll, S.; Schönfeld, P.; Körber, K.; Herrmann, J.V. Stadtbäume im Zeichen des Klimawandels: Erste Ergebnisse aus dem Projekt „Stadtgrün 2021“ und weitere Ausblicke. Jahrbuch der Baumpflege, 2014, pp. 155-170.

[27] Vierheiling, H.; Coughlan, A.P.; Wyss, U.; Piché, Y. Ink and vinegar, a Simple Staining Technique for Arbuscular-Mycorrhizal Fungi. Applied and Environmental Microbiology, 1998, 5004-5007.

[28] Hammer, Ø.; Harper, D.A.T. Paleontological Data Analysis, Blackwell, 2006.

[29] Calvet, C.; Pinochet, J.; Hernandez-Dorrego, A.; Estaun, V., Camprubi, A. Field microplot performance of the peach-almond hybrid GF-677 after inoculation with arbuscular mycorrhizal fungi in a replant soil infested with root-knot nematodes, Mycorrhiza, 2001, 10, 295-300.

[30] Fini, A.; Frangi, P.; Amoroso, G.; Piatti, R.; Faoro, M.; Bellasio, C.; Ferrini, F. Effect of controlled inoculation with specific mycorrhizal fungi from the urban environment on growth and physiology of containerized shade tree species growing under different water regimes,-- Mycorrhiza, 2011, 21(8), 703-19.

[31] Tschirner, E.; Brandt, C.; Deininger, D. Benefits of Mycorrhiza Inoculation of Trees and Bushes at Roadsides. In: Feldmann, F.; Kapulnik, Y.; Baar, J. Mycorrhiza Works DPG Publisher Braunschweig, German, 2008, pp. 295-303.

[32] Varghese, L. Organic vegetables issues and strategies - a review. Agricultural Reviews, 2000, 21 (4), 211-222. 